Розділ І. Ціннісні орієнтири духовно-інтелектуального виховання, розвиток духовно-інтелектуальних якостей особистості в умовах співпраці й інклюзії

\title{
ДУХОВНО-МОРАЛЬНЕ ВИХОВАННЯ СТАРШИХ ДОШКІЛЬНИКІВ В УМОВАХ СЬОГОДЕННЯ
}

\author{
Бакай С. Ю. \\ кандидат педагогічних наук, доцент \\ Харківський національний педагогічний університет імені Г. С. Сковороди, \\ м. Харків, Україна
}

У статті автор висвітлює проблему духовно-морального виховання дітей старшого дошкільного віку в умовах сьогодення, окреслює засоби морального виховання дітей у закладах дошкільної освіти та сім ї та середовищі.

Ключові слова: моральне виховання, духовно-моральне виховання, діти дошкільного віку, старший дошкільник.

In the article, the author highlights the problem of spiritual and moral education of children of older preschool age in the present, outlines the means of moral education of children in preschool and family and environment institutions.

Keywords: moral education, spiritual and moral education, preschool children, senior preschooler.

Сьогодні проблема морального виховання дітей різного віку, а зокрема дошкільного, надзвичайно гостро стоїть не тільки перед суспільством, а й перед освітянською громадою. Педагогічна спільнота намагається вирішити питання, яким чином прищепити сучасним дітям морально-духовні цінності, в основі якого стають вчинків людини, формується образ її особистості, визначається система цінностей і характер. Звичайно, сьогодні дитина знаходиться у колі величезного потоку інформації: ЗМІ, школа, ЗДО, кіно, Інтернет, і це скоріше сприяє розмиванню моральних норм і змушує нас дуже серйозно задуматися над проблемою ефективного морального виховання дітлахів.

Слід зазначити, що дитина здатна правильно оцінити і зрозуміти почуття й емоції іншої людини, поняття дружба, справедливість, співчуття, доброта, любов не є порожнім звуком, має набагато вищий рівень емоційного розвитку, не має проблем у спілкуванні з оточуючими, набагато стійкіше переносить стресові ситуації і не піддається негативному впливу ззовні. 
Безперечно, моральне виховання дошкільнят особливо важливе, тому що саме в цьому віці дитина особливо сприйнятлива до засвоєння моральних норм і вимог. Це одна з дуже важливих сторін процесу формування їі особистості. Духовно-моральне виховання дошкільників можна розглядати як безперервний процес засвоєння ними встановлених у суспільстві зразків поведінки, які надалі будуть регулювати іiі вчинки. У результаті такого морального виховання дитина починає діяти не тому, що хоче заслужити схвалення дорослого, а тому, що вважає за необхідне дотримання самої норми поведінки, як важливого правила у відносинах між людьми.

Науковці стверджують, що в дошкільному віці стрижнем, який визначатиме моральне виховання особистості дитини, є встановлення гуманістичних відносин між дітьми, опора на свої почуття, емоційна чутливість. У дитини емоції відіграють дуже важливу роль, вони допомагають реагувати на навколишню дійсність і формувати своє до неї ставлення, по мірі зростання малюка світ його емоцій розвивається і стає багатшим.

Сучасні наукові джерела наголошують, що моральне виховання дошкільників визначається тим, що в цей період малюк засвоює мову емоцій і почуттів, він опановує прийнятими в суспільстві формами вираження своїх переживань за допомогою всіляких словесних і несловесних засобів. Водночас дитина навчається стримувати себе в прояві своїх почуттів занадто бурхливих або різких. На відміну від дворічного, малюк у віці п'яти років вже може приховати свій страх або стримати сльози. Дитина опановує наукою управління своїми емоціями, навчається виявляти їх у прийнятій у суспільстві формі, користуватися своїми почуттями усвідомлено.

Безсумнівно, становлення емоційного середовища дошкільника найтіснішим чином пов' язано з його моральним вихованням і має свою динаміку. Так малюк, грунтуючись на прикладах 3 досвіду, складає розуміння того, що добре, а що погано, формує своє ставлення до жадібності, дружби тощо. Таке ставлення до основоположних понять нашого життя продовжує формуватися і надалі в міру дорослішання. Головним помічником дитини на цьому шляху є дорослий, який конкретними прикладами своєї поведінки і закладає в дитині основні моральні норми поведінки. Дитина формує найперші моральні оцінки і судження, починає розуміти, що таке моральна норма, і формує своє 
Розділ І. Ціннісні орієнтири духовно-інтелектуального виховання, розвиток духовно-інтелектуальних якостей особистості в умовах співпраці й інклюзії

ставлення до неї, що, однак, далеко не завжди забезпечує дотримання iï в реальних вчинках.

Відомо, що моральне виховання дітей відбувається на всьому протязі їх життя, і визначальне значення в становленні моральності дитини відіграє середовище, в якому вона розвивається і росте. Тому переоцінити важливість сім’ї в моральному вихованні дошкільнят неможливо. Способи поведінки, прийняті в сім’ї, дуже швидко засвоюються дитиною і сприймаються нею, як правило, в якості загальноприйнятої норми.

Хочемо зазначити, що найперша задача батьків полягає в тому, щоб допомогти дошкільнику визначитися з об'єктами його почуттів і зробити їх суспільно цінними. Почуття дозволяють людині відчути задоволення після здійснення правильного вчинку або змушують нас відчувати докори сумління, якщо моральні норми були порушені. Основа таких почуттів як раз і закладається в дитинстві, i завдання батьків допомогти в цьому своїй дитині. Обговорювати 3 нею моральні питання, домагатися формування ясної системи цінностей, щоб малюк розумів, які вчинки неприпустимі, а які бажані і схвалювані суспільством.

Слід зазначити, що ефективне моральне виховання неможливе без обговорення $з$ дитиною моральної сторони вчинків інших людей, персонажів художніх творів, вираження свого схвалення його моральних вчинків найбільш зрозумілим для малюка чином. Діти, у такому спілкуванні формують здатність виражати свої почуття, оцінювати їх, розвивають здатність до співпереживання і співчуття, дуже важливу в моральному вихованні малюка.

Доречи, у досягненні цієї мети відіграє використання музичного мистецтва, з яким діти стикаються від народження, а цілеспрямоване музичне виховання вони отримують в дитячому саду, школі тощо. Діти тонко сприймають музику, а вихователь та музичний керівник вчить мислити, відчувати, співпереживати почуте, орієнтуватися у світі музики, прищепити їм смак і долучати до вищих духовних цінностей, навчити пізнавати світ і формувати образ світу засобами мистецтва, в спілкуванні з мистецтвом музики зрозуміти себе і своє місце в світі. Діти мають обмежені уявлення про почуття людини, що виявляються в реальному житті, тому емоційна чуйність до музики допомагає виховувати такі якості особистості, як доброту, вміння співчувати іншій людині, співпереживати. 
Невміння висловити свої емоції, зрозуміти почуття оточуючих може призвести до формування «комунікативної глухоти», яка може стати причиною конфліктів дитини з іншими дітьми і негативно відбитися в процесі формування іiі особистості. Тому ще один дуже важливий напрямок морального виховання дітей, це - розвивати їх здібності до емпатії (співчуття). Важливо постійно звертати увагу дитини на те, які переживання вона відчуває, що відчувають оточуючі його люди, збагачувати лексикон малюка різними словами, що виражають переживання, емоції, почуття.

Завдання морального виховання старших дошкільників здатна вирішити гра, в якій дитина знайомиться з різними видами діяльності, засвоює нові для себе соціальні ролі, удосконалює комунікативні навички, вчиться виражати свої почуття й розуміти емоції інших людей, опиняється в ситуації, коли необхідна співпраця і взаємна допомога, накопичує первинний банк моральних уявлень і пробує співвідносити їx зі своїми вчинками, вчиться слідувати засвоєним моральним нормам і самостійно здійснювати моральний вибір.

Відомо, що у міру свого розвитку дитина приміряє на себе різні суспільні ролі, кожна з яких дозволить йому підготуватися до виконання різних соціальних обов'язків - учня, капітана команди, друга, сина чи дочки тощо. Кожна з таких ролей має величезне значення у формуванні соціального інтелекту і передбачає розвиток своїх власних моральних якостей: справедливості, чуйності, доброти, ніжності, турботи та ін., і чим різноманітніше буде репертуар ролей малюка, тим з більшою кількістю моральних принципів він познайомиться і тим багатшим буде його особа.

Таким чином, стратегія духовно-морального виховання у ЗДО і вдома повинна спрямовуватися не лише на усвідомлення своїх почуттів і переживань, на засвоєння суспільно значущих правил і норм поведінки, а й на розвиток почуття спільності з іншими людьми, формування позитивного ставлення до людей в цілому.

\section{Список використаних джерел:}

1. Богуш А. Духовність у педагогічному вимірі. Одеса : Друк, 2007. 88 с.

2. Духовно-моральне виховання дітей дошкільного віку: програма з духовно-морального виховання дошкільників: навч.-метод. посіб. / уклад. : В.В. Скрипник, В.С. Сучок; за ред. проф. В.М. Жуковського. 2-ге вид., 
Розділ І. Ціннісні орієнтири духовно-інтелектуального виховання, розвиток духовно-інтелектуальних якостей особистості в умовах співпраці й інклюзії

доп. і перероб. Острог : Вид-во Національного ун-ту «Острозька академія», $2012.48 \mathrm{c}$.

3. Педагогіка у запитаннях і відповідях : навч. посіб. / А. І. Кузьмінський, В. Л. Омеляненко. Київ, 2006. 311 с.

4. Тюріна Т. Духовна педагогіка: витоки, сутність і перспективи розвитку : монографія. Львів : СПОЛОМ, 2005. 276 с. 